ISSN 0258-7122

Bangladesh J. Agril. Res. 34(3) : 425-434, September 2009

\title{
EFFECT OF SEED TREATMENT AND FOLIAR SPRAY WITH FUNGICIDES IN CONTROLLING BLACK POINT DISEASE OF WHEAT
}

\author{
P.K. MALAKER ${ }^{1}$ AND I.H. MIAN ${ }^{2}$
}

\begin{abstract}
The efficacy of seed treatment and foliar spray with fungicides in controlling black point incidence of wheat seeds was evaluated in the field. Two seed treating fungicides, namely Vitavax-200 and Homai-80WP were used @ 0.25\% of dry seed weight and foliar spray with Tilt-250EC (0.05\%) was applied in six different schedules. Untreated and unsprayed controls were also maintained. Seed treatment with either Vitavax-200 or Homai-80WP significantly increased plant population and grain yield, but none of them was found effective in reducing black point incidence. On the other hand, foliar sprays with Tilt-250EC under all the spray schedules except spraying at 70 and 90 DAS significantly minimized the disease severity over unsprayed control. Among the different spray schedules, spraying at 30, 40, 50, 60, 70, 80, and 90 DAS appeared to be most effective, which was similar to spraying at 30, 45, 60, 75, and 90 DAS in reducing black point incidence and increasing grain yield. Economic analysis on yield advantage showed that the highest additional gross margin of Tk. 6120/ha with BCR 2.57 was obtained from five sprays applied at 30, 45, 60, 75, and 90 DAS.
\end{abstract}

Key Words: Seed treatment, foliar spray, black point, wheat.

\section{Introduction}

Black point caused mainly by Bipolaris sorokiniana and Alternaria alternata, is an important seed-borne disease of wheat in many wheat growing countries of the world including Bangladesh (Ahmed, 1986a; Fakir et al., 1987; Rahman et at, 1988; Fakir et al., 1989; Fakir, 1998; Zishan et al., 2005; Hasabnis et al., 2006). The disease is characterized by brown to black discolouration usually restricted to the germ end of the seeds. Black point symptom may also develop on the endosperm, ventral crease or even on the brush end of the grain. In case of severe infection, particularly when $B$. sorokiniana is involved, the grain may be completely discoloured and shrivelled. Impaired seed germination and significant reduction in seedling vigour and grain yield to black point infection have been reported at home and abroad (Khanum et al., 1987; Rahman and Islam, 1998; Hossain, 2000; Malaker and Mian, 2002). Black point also affects lustre and plumpness of wheat grain and reduces its market value (Rees et al., 1984; Chaudhary et al., 1984; Solanki et al., 2006).

\footnotetext{
${ }^{1}$ Senior Scientific Officer, Wheat Research Centre, BARI, Dinajpur-5200, ${ }^{2}$ Professor, BSMRAU, Gazipur-1706, Bangladesh.
} 
The basic principle involved in the control of a seed-borne disease is reducing the population of primary inoculum of the pathogen. Infected seeds are one of the most important sources of primary inoculum that survives between wheat cropping seasons (Reis, 1991). Thus use of healthy seeds provides a means of reducing primary inoculum and in turn reduces foliage infection and seedling blight. The predominant black point fungus, $B$. sorokiniana is highly seedtransmitted and more than $80 \%$ seed to plant transmission of this pathogen have been established in wheat (Reis et al., 1998). Use of seed treating fungicide is an option to reduce primary inoculum of B. sorokiniana and some other seed and soil-borne fungi (Ahmed, 1986b; Ali and Fakir, 1993; Meisner et al., 1994; Ilyas et al., 1998). Foliar spray with fungicide can control B. sorokiniana infection on foliage and reduce leaf blight severity of wheat (Rashid et al., 2001). However, limited work has been done on the chemical control of black point disease of wheat in Bangladesh. Although significant reduction of black point fungi and improvement in germination of black point affected seeds were achieved by seed treatment with fungicides (Fakir et al., 1984; Dey et al., 1992; Ali and Fakir, 1993), but no report on the control of black point incidence in the subsequent crop using seed treating fungicides is available. Fakir (1988) also found effective fungicide as foliar spray against black point incidence but an appropriate spray schedule is needed for proper management of the disease under field condition. The present study was, therefore, undertaken to determine the effectiveness of seed treatment and different schedules of foliar spray with fungicides in reducing black point incidence of wheat seeds under field condition.

\section{Materials and Method}

The experiment was conducted at Bangabandhu Sheikh Mujibur Rahman Agricultural University (BSMRAU), Salna, Gazipur, during 1999-2000 crop season. The seeds of a susceptible variety 'Kanchan' were collected from BARI and treated separately with two seed treating fungicides, namely Vitavax-200 (Carboxin 37.5\% + Thiram 37.5\%) and Homai8OWP (Thiophanate methyl 50\% + Thiram 30\%) at the rate of $2.5 \mathrm{~g} / \mathrm{kg}$ of dry seed weight. As foliar spray, Tilt250EC (Propiconazole) at $0.05 \%$ concentration of the formulated product was applied under six different spray schedules viz., i) 30, 50, 70, and 90 days after sowing (DAS); ii) 30, 45, 60, 75, and 90 DAS; iii) 30, 40, 50, 60, 70, 80, and 90 DAS; iv) 70 and 90 DAS; v) 60, 75, and 90 DAS; and vi) 60, 70, 80, and 90 DAS. Untreated and unsprayed controls were also maintained.

The land was prepared using a tractor driven disc plough, rotavator, and harrow. Well decomposed cowdung was applied at the rate of $10 \mathrm{t} / \mathrm{ha}$. Urea, TSP, MP, and gypsum were used at the rate of 220, 132, 68, and $125 \mathrm{~kg} / \mathrm{ha}$, respectively. Full doses of TSP, MP, and gypsum and two-thirds urea were applied during final land preparation. The rest one-third urea was applied as top 
dress after 20 days of sowing. The experiment was laid out in split-plot design with three replications. Seed treatment was assigned in the main plots and foliar spray in the sub-plots. The unit plot size was $2 \mathrm{~m} \mathrm{x} \mathrm{3m}$. Plot to plot and block to block distances were $1.0 \mathrm{~m}$ and $1.5 \mathrm{~m}$, respectively. The seeds were sown at the rate of $120 \mathrm{~kg} / \mathrm{ha}$ in continuous manner with $20 \mathrm{~cm}$ row spacing. Weeding was done twice at 25 and 45 DAS. Irrigations were applied at 20, 42, 63, and 80 DAS.

Data on seedling emergence per square meter were recorded after two weeks of sowing by counting the total number of seedlings in five linear meter selected randomly from middle five rows of each plot. Observations on post-emergence mortality were taken after three weeks of sowing in the same manner as followed for seedling emergence. Plant population was calculated by deducting the number of dead seedlings from those emerged per square meter. Number of spikes per square meter was noted before harvest following the same procedure as used for seedling emergence and post-emergence mortality. The crop was harvested at 115 DAS and data on black point infection of seed, length and weight of spike, number of grains per spike, 1000-grain weight, and grain yield were recorded. Black pointed grains per spike were recorded from 20 spikes selected randomly in each plot. Percentage of black pointed grains was calculated from 400 grains of composite sample taken from each plot. The grains were indexed for black point infection using 0-5 scale suggested by Gilchrist (1985). Data on disease parameters, yield and yield components were analyzed statistically using MSTAT-C computer programme and means were compared by DMRT. Economic analysis on yield advantage obtained from foliar sprays was also performed.

\section{Results and Discussion}

Seed treatment with either Vitavax-200 or Homai-8OWP had no significant effect on black point incidence but both the fungicides were equally effective in increasing plant population, number of spikes and grain yield (Table 1). Seedling mortality was found significantly lower in plots sown to seeds treated with either Vitavax-200 or Homai-8OWP than to sowing with untreated seeds. Number of grains per spike was increased significantly by using both the fungicides but the effect was more pronounced when Vitavax-200 was used However, no significant increase in spike length, spike weight or 1000-grain weight was observed when the seeds were treated with any of the two fungicides. The increase in grain yield due to seed treatment was attributed to increase in number of spikes per square meter and grains per spike.

When foliar spray with Tilt-250EC was applied, a significant reduction in severity of black point infection was observed under different spray schedules except $\mathrm{S}_{4}$ (spray at 70 and 90 DAS) as compared to unsprayed control (Table 2). The minimum percentage of leaf blight index was recorded under $S_{3}$ (spray at 30 , 
Table 1. Effect of fungicidal seed treatment on black point incidence and grain yield of wheat.

\begin{tabular}{|c|c|c|c|c|c|c|c|c|c|c|c|}
\hline $\begin{array}{l}\text { Seed } \\
\text { treatment with }\end{array}$ & $\begin{array}{c}\text { Black } \\
\text { pointed } \\
\text { seeds/spike }\end{array}$ & $\begin{array}{c}\text { \%Black } \\
\text { pointed } \\
\text { grain }\end{array}$ & $\begin{array}{c}\text { Black } \\
\text { pointed } \\
\text { index (\%) }\end{array}$ & \begin{tabular}{|c|} 
Plant \\
population \\
$/ \mathrm{m}^{2}$
\end{tabular} & $\begin{array}{c}\text { Seedling } \\
\text { mortality } \\
(\%)\end{array}$ & Spikes/m² & $\begin{array}{l}\text { Spike } \\
\text { length } \\
(\mathrm{cm})\end{array}$ & $\begin{array}{l}\text { Spike } \\
\text { weight } \\
\text { (g) }\end{array}$ & $\begin{array}{l}\text { Grains } \\
\text { /spike }\end{array}$ & $\begin{array}{l}100- \\
\text { grain } \\
\text { wt (g) }\end{array}$ & $\begin{array}{c}\text { Grain } \\
\text { yield } \\
\text { (kg/ha) }\end{array}$ \\
\hline Vitavax-200 & 3.99 a & $\begin{array}{l}10.59 \mathrm{a} \\
(3.18)\end{array}$ & $\begin{array}{l}4.37 \mathrm{a} \\
(2.13)\end{array}$ & $185 \mathrm{a}$ & $\begin{array}{l}1.42 \mathrm{~b} \\
(1.37)\end{array}$ & 395 a & $10.33 \mathrm{a}$ & $2.12 \mathrm{a}$ & 35.93 a & $46.78 \mathrm{a}$ & 3846 a \\
\hline Homai-80WP & $4.30 \mathrm{a}$ & $\begin{array}{l}11.70 \mathrm{a} \\
(3.33)\end{array}$ & $\begin{array}{l}5.25 \mathrm{a} \\
(2.31)\end{array}$ & $180 \mathrm{a}$ & $\begin{array}{l}1.72 \mathrm{~b} \\
(1.48)\end{array}$ & $380 \mathrm{a}$ & $10.22 \mathrm{a}$ & $2.09 \mathrm{a}$ & $35.36 \mathrm{~b}$ & $46.63 \mathrm{a}$ & 3725 a \\
\hline Untreated & $4.85 \mathrm{a}$ & $12.82 \mathrm{a}$ & $5.53 \mathrm{a}$ & $157 \mathrm{~b}$ & $4.83 \mathrm{a}$ & $343 \mathrm{~b}$ & 10.19 a & $2.07 \mathrm{a}$ & $34.89 \mathrm{c}$ & $46.26 \mathrm{a}$ & $3396 \mathrm{~b}$ \\
\hline Control & & (3.50) & (2.37) & & (2.29) & & & & & & \\
\hline
\end{tabular}

Means within a column followed by a common letter do not differ significantly $(p=0.05)$.

Data in parentheses are square root $(\mathrm{x}+0.5)$ transformed values. 
Table 2. Effect of different schedules of foliar spray with TiIt-250EC on black point incidence and grain yield of wheat.

\begin{tabular}{|c|c|c|c|c|c|c|c|c|c|}
\hline $\begin{array}{c}\text { Spray } \\
\text { schedules* }\end{array}$ & \begin{tabular}{|c|}
$\begin{array}{c}\text { Black pointed } \\
\text { seeds/spike }\end{array}$ \\
\end{tabular} & $\begin{array}{c}\text { \%Black } \\
\text { pointed grain }\end{array}$ & \begin{tabular}{|c|} 
Black pointed \\
index $(\%)$
\end{tabular} & Spikes $/ \mathrm{m}^{2}$ & \begin{tabular}{|c|} 
Spike \\
length $(\mathrm{cm})$ \\
\end{tabular} & \begin{tabular}{|c|} 
Spike \\
weight (g)
\end{tabular} & $\begin{array}{l}\text { Grains } \\
\text { /spike }\end{array}$ & $\begin{array}{c}100 \text {-grain } \\
\text { wt (g) }\end{array}$ & $\begin{array}{c}\begin{array}{c}\text { Grain yield } \\
(\mathrm{kg} / \mathrm{ha})\end{array} \\
\end{array}$ \\
\hline $\mathrm{S}_{1}$ & $2.37 \mathrm{e}$ & $\begin{array}{l}6.23 \mathrm{e} \\
(2.57)\end{array}$ & $\begin{array}{l}2.73 \mathrm{~d} \\
(1.79)\end{array}$ & 382 a & $10.41 \mathrm{ab}$ & $2.12 \mathrm{c}$ & $36.44 \mathrm{~b}$ & $47.91 \mathrm{ab}$ & $3724 a b$ \\
\hline $\mathrm{S}_{2}$ & $1.94 \mathrm{e}$ & $\begin{array}{l}5.07 \mathrm{f} \\
(2.35)\end{array}$ & $\begin{array}{l}2.32 \text { de } \\
(1.67)\end{array}$ & $375 \mathrm{ab}$ & 10.49 a & $2.20 \mathrm{~b}$ & 38.16 a & $48.28 \mathrm{ab}$ & 3791 a \\
\hline $\mathrm{S}_{3}$ & $1.78 \mathrm{e}$ & $\begin{array}{l}4.56 \mathrm{f} \\
(2.23)\end{array}$ & $\begin{array}{l}2.21 \mathrm{e} \\
(1.63)\end{array}$ & 381 a & 10.61 a & $2.32 \mathrm{a}$ & 39.13 a & $49.06 \mathrm{a}$ & 3812 a \\
\hline $\mathrm{S}_{4}$ & $7.64 \mathrm{~b}$ & $\begin{array}{l}20.61 \mathrm{~b} \\
(4.58)\end{array}$ & $\begin{array}{l}8.79 \mathrm{a} \\
(3.03)\end{array}$ & $367 \mathrm{~b}$ & $10.00 \mathrm{~cd}$ & $2.00 \mathrm{~d}$ & 32.93 de & $44.37 \mathrm{~d}$ & $3540 \mathrm{~cd}$ \\
\hline $\mathrm{S}_{5}$ & $4.58 \mathrm{c}$ & $\begin{array}{l}12.38 \text { c } \\
(3.57)\end{array}$ & $\begin{array}{l}5.78 \mathrm{~b} \\
(2.50)\end{array}$ & $368 \mathrm{~b}$ & 10.llbc & $2.03 \mathrm{~d}$ & $34.38 \mathrm{~cd}$ & $45.95 \mathrm{c}$ & $3607 \mathrm{bcd}$ \\
\hline $\mathrm{S}_{6}$ & $3.72 \mathrm{~d}$ & $\begin{array}{l}9.92 \mathrm{~d} \\
(3.21)\end{array}$ & $\begin{array}{l}3.96 \mathrm{c} \\
(2.10)\end{array}$ & $368 \mathrm{~b}$ & $10.32 \mathrm{abc}$ & $2.07 \mathrm{~cd}$ & 34.93 bc & $47.47 \mathrm{~b}$ & 3656 abc \\
\hline $\mathrm{S}_{7}$ & 8.63 a & $\begin{array}{l}23.14 \mathrm{a} \\
(4.84)\end{array}$ & $\begin{array}{l}9.54 \mathrm{a} \\
(3.16)\end{array}$ & $368 \mathrm{~b}$ & $9.78 \mathrm{~d}$ & $1.90 \mathrm{e}$ & 31.77 e & $42.86 \mathrm{e}$ & $3457 \mathrm{~d}$ \\
\hline
\end{tabular}

*Spray schedules: $\mathrm{S}_{1}=30,50,70$, and $90 \mathrm{DAS} ; \mathrm{S}_{2}=30,45,60,75$, and $90 \mathrm{DAS} ; \mathrm{S}_{3}=30,40,50,60,70,80$, and 90 DAS; $\mathrm{S}_{4}=70$ and 90 DAS; $S_{5}=60,75$ and 90 DAS; $S_{6}=60,70,80$ and 90 DAS; and $S_{7}=$ Unsprayed.

Means within a column followed by a common letter do not differ significantly $(\mathrm{p}=0.05)$.

Data in parentheses are square root $(\mathrm{x}+0.5)$ transformed values. 
40, 50, 60, 70, 80, and 90 DAS) and it was statistically similar to that observed under $\mathrm{S}_{2}$ (spray at 30, 45, 60, 75, and 90 DAS) but differed significantly from other spray schedules. The percentages of leaf blight index recorded under $\mathrm{S}_{1}$ (spray at 30, 50, 70, and $90 \mathrm{DAS}$ ), $\mathrm{S}_{5}$ (spray at 60,75, and $90 \mathrm{DAS}$ ) and $\mathrm{S}_{6}$ (spray at $60,70,80$, and 90 DAS) were statistically similar. Number of black pointed grains per spike, percent black pointed grains and percent black point index were significantly lower under $S_{3}$ as compared to other spray schedules except $S_{2}$. The highest number of spikes per square meter was found under $S_{1}$, which was statistically similar to $S_{2}$ and $S_{3}$, but significantly higher as compared to all other spray schedules. Significantly higher spike length was recorded under $S_{1}, S_{2}, S_{3}$ and $S_{6}$ as compared to $S_{4}, S_{5}$, and $S_{7}$ (unsprayed control). Significantly the highest spike weight was recorded under $S_{3}$, which was followed by $S_{2}$, and $S_{1}$, while the lowest spike weight was observed under $S_{7}$. The number of grains per spike was the highest under $S_{3}$, which was statistically similar to $S_{2}$, but significantly higher as compared to all other spray schedules. The 1000-grain weight was significantly higher under all the spray schedules as compared to unsprayed control. The highest 1000-grain weight was recorded under $S_{3}$ and it was statistically similar to $S_{1}$ and $S_{2}$. The highest grain yield was also obtained from $S_{3}$, which was statistically similar to $S_{1}, S_{2}$, and $S_{6}$. The lowest yield was obtained from unsprayed control, which was statistically similar to $S_{4}$ and $S_{5}$. The interaction effects of seed treatment and foliar spray on black point incidence and grain yield were insignificant and have not been included in discussion.

The findings of the present study indicate that seed treatment with Vitavax200 and Homai-80WP significantly increased plant population and grain yield in wheat although both of them were found ineffective in reducing the incidence of black point disease. Improved seed germination and grain yield by seed treatment with various seed dressing fungicides have also been reported by other workers (Sinha and Thapliyal, 1984; Ahmed, 1986; Kamaluddin, 1996; Ilyas et al., 1998). Meisner et al (1994) found that seed treatment with Vitavax-200 increased plant stand by $23 \%$ and grain yield by $18 \%$ under farmer's field condition. The average grain yields of Kanchan as observed under untreated and unsprayed controls were almost similar to those recorded earlier in different trials conducted in research stations under normal crop management practices (Ahmed and Meisner, 1996). The ineffectiveness of fungicidal seed treatment against black point incidence was probably due to the fact that the reduction of seed-borne inocula in early growth stage was not enough to reduce severity of black point incidence in the harvested seeds. The inocula coming from soil and other sources (Reis et al., 1998) might have also played role in reducing the efficacy of seed treating fungicides against black point incidence. On the other hand, foliar spray with Tilt 250EC (0.05\%) under different spray schedules was found effective in controlling the disease. All the spray schedules except spraying at 70 and 90 DAS significantly minimized the severity of black point infection over unsprayed 
Table 3. Economic analysis on yield advantage obtained from foliar spray with Tilt-250EC in controlling black point incidence of wheat.

\begin{tabular}{|c|c|c|c|c|c|c|c|c|c|}
\hline \multirow{2}{*}{$\begin{array}{c}\text { Spray } \\
\text { schedules* }\end{array}$} & \multirow{2}{*}{$\begin{array}{c}\text { Yield } \\
\text { advantage over } \\
\text { unsprayed } \\
\text { control (kg/ha) }\end{array}$} & \multirow{2}{*}{$\begin{array}{l}\text { Additional } \\
\text { Gross Return } \\
\text { (Tk./ha) }\end{array}$} & \multirow{2}{*}{$\begin{array}{l}\text { No. of } \\
\text { spray }\end{array}$} & \multirow{2}{*}{$\begin{array}{l}\text { Quantity of } \\
\text { Tilt 250EC } \\
\text { @ 0.5L/ha/ } \\
\text { spray (L/ha) }\end{array}$} & \multicolumn{3}{|c|}{ Cost spraying (Tk./ha) } & \multirow{2}{*}{$\begin{array}{l}\text { Additional } \\
\text { Gross Margin } \\
\text { (Tk./ha) }\end{array}$} & \multirow[t]{2}{*}{ BCR } \\
\hline & & & & & $\begin{array}{l}\text { Tilt- } \\
\text { 250EC }\end{array}$ & Labour & Total & & \\
\hline $\mathrm{S}_{1}$ & 267 & 8010 & 4 & 2 & 2400 & 720 & 3120 & 4890 & 2.57 \\
\hline $\mathrm{S}_{2}$ & 334 & 10020 & 5 & 2.5 & 3000 & 900 & 3900 & 6120 & 2.57 \\
\hline $\mathrm{S}_{3}$ & 355 & 10650 & 7 & 3.5 & 4200 & 1260 & 5460 & 5190 & 1.95 \\
\hline $\mathrm{S}_{4}$ & 83 & 2490 & 2 & 1 & 1200 & 360 & 1560 & 930 & 1.60 \\
\hline $\mathrm{S}_{5}$ & 150 & 4500 & 3 & 1.5 & 1800 & 540 & 2340 & 2160 & 1.92 \\
\hline $\mathrm{S}_{6}$ & 199 & 5970 & 4 & 2 & 2400 & 720 & 3120 & 2850 & 1.91 \\
\hline
\end{tabular}

*Spray schedules: $S_{1}=30,50,70$, and 90 DAS; $S_{2}=30,45,60,75$, and 90 DAS; $S_{3}=30,40,50,60,70,80$, and 90 DAS; $S_{4}=70$ and 90 DAS; $\mathrm{S}_{5}=60,75$ and 90 DAS; $\mathrm{S}_{6}=60,70,80$ and 90 DAS.

Price: Wheat $=$ Tk. 30/kg; Tilt-250EC $=$ Tk. 1200,1; Labour $=$ Tk. 180/ha/spray 
control. Among the spray schedules, spraying at 30, 40, 50, 60, 70, 80, and 90 DAS appeared to be most effective, which was similar to spraying at $30,45,60$, 75 , and 90 DAS in reducing disease severity and increasing grain yield. The effectiveness of Tilt 250EC in controlling Bipolaris leaf blight and black point infection was also reported by other workers (Lapis, 1985; Duveiller and Gilchrist, 1994; Singh et al., 1995; Mahto, 1999). The results of the present study were also in agreement with the findings of Rashid et al. (2001), who reported that foliar spray with Tilt $250 \mathrm{EC}$ at $0.1 \%$ concentration successfully controlled $B$. sorokiniana infection on foliage and reduced black point incidence in grains.

The economic analysis on yield advantage obtained from foliar sprays of Tilt-250EC revealed that the additional gross margin varied with the number of sprays applied under different schedules and the respective amount of yield increase over unsprayed control (Table 3). The highest additional gross margin of Tk. 6120/ha with BCR 2.57 was obtained from five sprays applied at 30, 45, 60, 75, and 90 DAS. Four sprays applied at 30, 50, 70, and 90 DAS gave the additional gross margin of Tk. 4890/ha with the same BCR. The second highest additional gross margin of Tk. 5190/ha was obtained from seven sprays but with lower BCR, which was more or less similar to those of three sprays applied at 60 , 75 , and 90 DAS and four sprays applied at 60, 70, 80, and 90 DAS. The lowest additional gross margin with the lowest BCR was obtained from two sprays applied at 70 and 90 DAS.

\section{Conclusion}

Seed treatment with either Vitavax-200 or Homai-80WP was found ineffective in reducing black point incidence but increased plant population and grain yield. Foliar sprays with Tilt-250EC under different schedules except two sprays applied at 70 and 90 DAS were found effective in reducing the incidence of black point disease in wheat grains. From the economic point of view, five sprays applied at 30, 45, 60, 75, and 90 DAS and four sprays applied at 30, 50, 70, and 90 DAS were found more profitable compared to all other spray schedules.

\section{References}

Ahmed, H.U. 1986a. Prevailing wheat diseases in Bangladesh. pp. 124-134. In: Third National Wheat Training Workshop (Anonymous, Ed.). Wheat Research Centre, BARI, Joydebpur, Gazipur.

Ahmed, H.U. 1986b. Recommendations on the Methods of Disease Management of Crops in Bangladesh. Plant Pathology Division, BARI, Joydebpur, Gazipur. 65 pp.

Ahmed, S.M. and C.A. Meisner. 1996. Wheat Research and Development in Bangladesh. Bangladesh-Australia Wheat Improvement Project and CIMMYT-Bangladesh. 201 pp.

Ali, M.H. and G.A. Fakir. 1993. Control of seed-borne fungi of wheat with fungicides. Bangladesh.J. Bot. 22(2): 135-141. 
Chaudhary, R.C., S.S. Aujla, I. Sharma and R.P. Singh. 1984. Effect of black point on germination and quality characters ofWL-711. Indian Phytopath. 37: 35 1-353.

Dey, T.K., N. Chowdhury, A. Ayub and B.K. Goswami. 1992. Black point of wheat: Occurrence, effect of fungicidal seed treatment on germination and quality characters. Bangladesh J. Bot. 21(1): 27-32.

Duveiller, E. and L. Gilchrist. 1994. Production constraints due to Bipolaris sorokiniana in wheat: Current Situation and Future Prospects. pp. 343-352. In: Wheat in Heat Stressed Environments: Irrigated, Dry Areas and Rice-Wheat Farming Systems (D.A. Saunders and G.P. Hettel, Eds.). Mexico, D.F., CIMMYT.

Fakir, G.A. 1988. Report on investigation into black point disease of wheat in Bangladesh. Bangladesh-German Seed Development Project. Dhaka. 99 pp.

Fakir, G.A. 1998. Black point disease of wheat in Bangladesh. 2nd Edition. Seed Pathology Laboratory, Bangladesh Agricultural University, Mymensingh. 81 pp.

Fakir, G.A., M.H. Rahman and G.M.M. Rahman. 1989. Survey on the prevalence of black point fungi of wheat in Bangladesh. Bangladesh.J. Plant Pathol. 5(1\&2): 19-29.

Fakir, G.A., S. Swanda and S.B. Mathur. 1984. Control of seedborne infection of Drechslera sorokiniana and Septoria nodorum in wheat by Panoctine/CG 450. In: Proc. of 9th Bangladesh Ann. Sci. Conf. Sec. I. p. 62.

Fakir, G.A., G.M.M. Rahman, M.R. Islam, M.H. Rahman and K.A. Talukder. 1987. Black point of wheat-A review. Bangladesh.J. Plant Pathol. 3(1\&2): 1-11.

Gilchrist, L.I. 1985. CIMMYT methods for screening wheat for Helminthosporium sativum resistance. pp. 149-151. In: Wheat for More Tropical environments: A Proceeding of the thternational Symposium, September 24-28, 1984. Mexico, D.F.: CIMMYT.

Hasabnis, S.N., B.M. Ilhe and V.K. Shinde. 2006. Incidence of black point disease in wheat varieties. J. Maharashtra Agric. Univ. 31(1): 114-115.

Hossain, M.M. 2000. Effect of different levels of black pointed seeds on germination, seedling vigour, plant stand and seed quality of wheat. M.S. Thesis. Department of Plant Pathology, Bangladesh Agricultural University, Mymensingh. 82 pp.

Ilyas, M.B., S.A.A. Bokhari and M.A. Khan. 1998. Fungi detected from wheat seeds exhibiting black point symptoms and their control by seed treatment. Pakistan $J$. Phytopathol. 10(2): 86-89.

Kamaluddin. 1996. Effect of seed treatment on plant population and yield of wheat. M.Sc.(Ag.) Thesis. Bangladesh Agricultural University, Mymensingh. 62 pp.

Khanum, M., Y. Nigar and A.K. Khanzada. 1987. Effect of black point disease on the germination of wheat varieties. Pakistan J. Agril. Res. 8(4): 467-473.

Lapis, D.B. 1985. Chemical control of wheat diseases in the Philippines. pp. 204-208. In: Wheat for more Tropical Environments: A Proceedings of the International Symposium, September 24-28, 1984, Mexico, D.F.: C]MMYT.

Mahto, B.N. 1999. Management of Helminthosporium leaf blight of wheat in Nepal. Indian Phytopath. 52(4): 408-413. 
Malaker, P.K. and I.H. Mian. 2002. Effect of black point on seed quality and yield of wheat. Bangladesh J. Plant Pathol. 18(1\&2): 65-70.

Meisner, CA., M. Badaruddin, D.A. Saunders and K.B. Alam. 1994. Seed treatment as a means to increase wheat yields in warm areas. pp. 360-366. In: Wheat in HeatStressed Environments: Irrigated, Dry Areas and Rice-Wheat Farming Systems (D.A. Saunders and liP. Hettel, Eds.). Mexico, D.F.: CIMMYT.

Rahman, G.M.M. and M.R. Islam. 1998. Effect of black point of wheat on some qualitative characters of its grain and seed vigour. Bangladesh J. Agril. Res. 23(2): 283-287.

Rahman, M.H., GA. Fakir, G.M.M. Rahman and M.R. Islam. 1988. Survey on the $\mathrm{V}$ prevalence of black point of wheat in Bangladesh. Bangladesh J. Plant Pathol. 4(1\&2): 35-42.

Rashid, A.Q.M.B., K. Sarker and K.M. Khalequzzaman. 2001. Control of Bipolaris leaf blight of wheat with foliar spray of Tilt 250 EC. Bangladesh J. Plant Pathol. 17(1\&2): 45-47.

Rees, R.G., D.J. Martin and D.P. Law. 1984. Black point in bread wheat: Effect on quality and germination and fungal association. Aust. J Exp. Agric. Anim. Husb. 24: 601-605.

Reis, E.M. 1991. Integrated disease management The changing concepts of controlling head blight and spot blotch. pp. 165-177. In: Wheat for the Nontraditional Warm Areas (D.A. Saunders, Ed.). Mexico, D.F.: CIMMYT.

Reis, E.M., C.A. Medeiros and R.T. Casa. 1998. Control of leaf blights of wheat by Helimination of the inoculum source. pp. 327-332. In: Helminthosporium Blights of Wheat: Spot Blotch and Tan Spot (E. Duveiller, H.J. Dubin and A. MeNab, Eds.). Mexico, D.F.: CIMMYT.

Sinha, A.P. and P.N. Thapliyal. 1984. Seed disinfection in relation to black point disease of triticale. Indian Phytopath. 37: 54-56.

Singh, R.V., A.K. Singh, D. Singh, S.P. Singh and V.P. Choudhury. 1995. Management of foliar blight of wheat through chemicals. Indian J. MycoL Plant Pathol. 25(1\&2): 113.

Solanki, V.A., N. Augustine and A.A. Patel. 2006. Impact of black point on wheat trade and its management. Indian Phytopath. 59(3): 44-47.

Zishan, U., S.J.A. Shah and H. Shaukat. 2005. Studies on incidence of black point in different wheat cultivars grown in Pakistan. Sarhad J. Agric. 21(4): 723-728. 